\title{
External Causes of Illness
}

If an illness was to be understood, diagnosed, and treated, it was crucial in medical practice to identify its cause within the body, above all the nature and location of the morbid matter in question. However, contemporary medicine also paid great heed to external causes that could trigger or promote a disease. Such causes helped explain what had set a pathological process in motion in the first place. Particularly in the case of chronic illness, the seed of the sickness in a specific body part had already been present early on, indeed perhaps since birth, as people believed. When, however, it was met with, to use Handsch's words, "disorder [...] be it with eating, drinking, anger, insult, chagrin, or other symptoms", the disease became manifest. ${ }^{131}$ In Handsch's experience, patients and their relatives demanded such an explanation. They wanted the physician to explain to them where the disease had come from and they expressed their own assumptions in ways such as, "He has eaten or drunk it" or he "had a sudden drink when [he was] heated, and so harmed the liver"; it "came to him when he got a fright", he "crossed an evil trail", or "it was done to him". ${ }^{132}$

\section{Environment and Lifestyle}

Physicians considered environmental influences and an individual's way of life to play a key role in the development of disease. According to the well-established doctrine of the six "non-natural things" or "res non naturales", there were six particular factors relating to an individual's life circumstances that physicians considered the triggers or "first causes" of disease: air and environment, eating and drinking, sleep and rest, exertion and leisure, the passions, and excretions. We will be coming back to these in the chapter on dietetics as it was crucial to control these factors to maintain health and fight diseases. The focus of this current chapter is on their etiological role, on their importance as causes of disease.

The famous Hippocratic treatise De aere, aquis et locis had already lent great weight to the influence of the air and the local environment on human health. In the sixteenth century, numerous Greek and Latin editions of the work

131 Cod. 11206, fol. 125r, "es sei mit Essen, Trincken, Zorn, Harm, Bekummernuß, oder anderen Zufellen".

132 Cod. 11205, fol. 425v: "Er hat es gessen, aber [oder, M.S.] getruncken”; "auf Hitz gehling [jäh, M.S.] getruncken, das er der Leber geschadet”; "ym aus Schrecken kommen”; “eyn böse Spur ubergangen”; “es ym gethan”.

Ә Open Access. (C) 2022 Michael Stolberg, published by De Gruyter. (cc) BY-NC-ND This work is licensed under the Creative Commons Attribution-NonCommercial-NoDerivatives 4.0 International License. https://doi.org/10.1515/9783110733549-007 
appeared in print. ${ }^{133}$ As Handsch learned as a student in Padua, air was particularly important because it contributed to the production of the vital spirits and the spirits of the soul and thus had a significant influence on their quality. Healthy air was clear, delicate, and moved easily. Foggy and turbid or spoiled air and fumes, on the other hand, particularly when emanating from swamps, sewers, and burial chambers, were considered to be significant causes of individual illnesses and epidemics. ${ }^{134}$ Certain occupations too, especially mining and metalworking, exposed the body to harmful, poisonous air. If a goldsmith fell ill, it was appropriate to say, according to Handsch's notes, "You have harmed yourself with gilding, which is a concern because of the mercury", or in the case of an ill cloth dyer, "You have harmed yourself with dyeing; the steam from the kettle went into your mouth". 135

The fact that food first had to be concocted and assimilated already implied that its quantity and quality played a central role in health. The excessive consumption of food and the enjoyment of raw, cool, slimy food, or anything that for any other reason was difficult to concoct overtaxed the stomach and the vital heat and contributed to an accumulation of mucous, potentially pathological matter. A physician in this situation could say, "He overate. Overburdened his stomach", 136 or "Eating cold dishes makes for a disorderly stomach". ${ }^{137}$ When asked, he could explain more closely that the disease in question came from "disorder in eating and drinking, and especially in drinking", in the course of which "bad moistures" accumulated and ultimately emptied like an overflowing pond into the body. ${ }^{138}$ Certain kinds of food and drink on the other hand - red wine especially - were considered to have a heating effect instead and could thus amplify the effects of the extrinsic heat of a fever. In this case, the physician could explain that the blood was "heated, inflamed, burnt, spoilt due to excessive drinking". 139

Experience taught that a moderate degree of physical exertion and movement, which did not excessively heat and exhaust the body, strengthened the limbs and enhanced the natural vital heat which then more effectively concocted

133 Hippocrates, De aere (1529).

134 Cod. 11210, fol. 43v.

135 Cod. 11205, fol. 192r: "Yr habt eucht mit dem Übergulden verterbt, denn solchs ist sorglich wegen des Quecksilbers." "Yr habt euch mit dem Ferben verterbt, das euch der Dampff vom Kessel ynns Maul gangen.”

136 Cod. 11206, fol. 171r: "Er hat sich übergessen. Den Magen überladen."

137 Ibid., fol. 172r: "Kalt Speiß essen macht ein ungeschickten Magen.”

138 Ibid., fol. 119r.

139 Ibid., fol. 185v, “erhitzt, entzundt, verbrennet, verterbet, auß überflüssigem Trincken”. 
the food into good, invigorating blood. Moreover physical exercise stimulated the vital spirits, opened the pores of the skin, and perspiration was increased. ${ }^{140}$

While a person slept, the vital heat was able to concentrate entirely on the concoction of food. ${ }^{141}$ Handsch's succinct comment on this is, "Sleep helps digestion". ${ }^{142}$ Furthermore, the mental faculties ("facultates animales") found rest during sleep. Not getting enough sleep, on the other hand, weakened the faculties of the senses and the mind and led to the generation of raw matter ("cruditatem"). Possible consequences could even be delirium and frenzy ("phrenesis"). ${ }^{143}$

Excretions occupied a special position. ${ }^{144}$ In the discussions of the res non naturales, they often occupied the most central position, as they do in Handsch's student notes on the subject. ${ }^{145}$ By way of introduction, he referred to the chapter about them as "a long, useful, and necessary chapter". ${ }^{146}$ With the relatively rare exception of a very excessive loss of excremental matter, in particular of menstrual blood, excretions did not rank as a major cause of diseases, however. Not the excretions per se but their obstruction was the major issue, since they were considered the most important means by which the body could fight diseases. Moreover, leaving medicines aside, they were subject to human control to a very limited extent only, mostly through the choice of suitable foodstuffs, i.e. through one of the other non-naturals.

The emotions, finally, or, in the learned terminology of the time, the affects of the mind ("affectus animi") or passions or accidents of the soul ("accidentia animae"), were thought to have a particularly great and powerful influence on the body and on health, ${ }^{147}$ and laypeople widely shared this belief. In Handsch's experience, patients often said that worries, grief, or fear had weakened them. ${ }^{148}$ When sick people wanted to know the cause of their suffering, as they so often did, the physician, Handsch found, could therefore hardly be wrong when he said, "You have stirred it awake with worries and concern or fright."149

140 Cod. 11210, fol. 50v.

141 Ibid., fol. 52r.

142 Cod. 11206, fol. 185r: "Der Schlaff hilfft zur Dewung."

143 Cod. 11210 , fol. 52v.

144 On what follows, see also Stolberg, Keeping the body open (2020).

145 Cod. 11210 , foll. $53 \mathrm{v}-67 \mathrm{v}$.

146 Ibid., fol. $53 \mathrm{v}$.

147 Cf. Stolberg, Zorn (2005); idem, Emotions (2019).

148 Cod. 11205, fol. 542r.

149 Ibid., fol. 434r: "Yr habt es zum ersten Mal aus Bekummernus und Anfechtungen aber [oder, M.S.] Erschrecken erwecket.” 
The prominent place of the emotions in 16th-century disease theory calls for some explanation. Renaissance physicians - and early modern medicine in general, for that matter - I largely interpreted emotions to be physical phenomena. ${ }^{150}$ Handsch's Padua notes on this echo the contemporary doctrine well, albeit with a few slight variations. In the common interpretation, which Handsch adopted, fear caused the vital heat, blood, and vital spirits to withdraw into the body's interior. The extremities and the skin became cold, the pulse weak and sometimes the "retentive faculty", the facultas retentiva, was so weakened by the lack of vital heat that the affected person would not be able to hold in urine and feces. ${ }^{151}$ This was at the origin of the expression "He was so afraid that he soiled and wet himself", Handsch added. ${ }^{152}$ Shame was a lighter form of fear. As with fear, the heat withdrew into the inside at first but was then sent in the opposite direction, making the cheeks flush. ${ }^{153}$ In the case of anger, very hot blood gushed into the heart, and the vital spirits that streamed to the rest of the body and heated it were accordingly hot, ${ }^{154}$ which, in the worst case, could have pathological consequences. Here, the physician might say, "His disease comes from his irritation". With joy, the vital spirits likewise streamed to the outside, and in the extreme case this would be so sudden and violent that the person would fall down dead on the spot. ${ }^{155}$ With sadness, the heart became constricted. ${ }^{156}$ Grief but also dread, and fear could, according to Handsch's notes, likewise have deadly consequences because the heart literally suffocated. ${ }^{157}$

Other contemporary texts explained this at greater length. They commonly associated not only dread but also fear with a distinct physical sensation - one which we can still relate to today - of constriction and pressure in the chest, in the area around the heart. The German word "Angst" and the English word "anguish" still show this connection: both come from the Latin word "angustia" ("tightness") or "angustus" ("narrow"). This feeling of tightness and pressure lent support to the notion that blood and vital spirits were withdrawing from the rest of the body and accumulating in the limited space of the heart and the surrounding area. The connection between fear and the feeling of tightness or

150 Argenterio, De morbis (1556), p. 218.

151 Cod. 11210, fol. 68r.

152 Ibid., fol. 68r: "Er hat sich vor Furcht beschissen unnd beseicht."

153 Ibid.

154 Ibid.

155 Ibid.: "Sein Kranckheit kompt im von Unmutt."

156 Cod. 11210, fol. 68r.

157 Ibid. 
narrowness was so strong at the time that both physicians and laypeople sometimes spoke of “Angst”, in German, when they were clearly not trying to describe the emotion but rather the physical sensation of tightness and pressure, as might occur with dropsy, for example. ${ }^{158}$ In sum: because the emotions were explained and experienced primarily as physical phenomena it was plausible to assume that they could act as a major cause of diseases.

\section{The Moon, Stars, and Seasons}

Astrology was an important branch of early modern natural history, and learned physicians played an important role in it. ${ }^{159}$ Medical astrology could look back on a long tradition. Medieval medicine, drawing on the ancient authorities, considered the stars and planets to have a great influence on health and human life in general. The Zurich city physician Christoph Clauser explained that "Through experience I know that the work of a physician is incomplete without considering the stars". ${ }^{160}$ Among Renaissance scholars, however, there was lively discussion about the status and scope of astrological predictions. Some astrologists claimed that the planets directly determined the life of the individual and all future occurrences on Earth. Others rejected the idea not least of all on religious grounds. For critics, such a predetermination did not seem compatible with divine omnipotence. Less problematic and thus more palatable was the assumption that the stars merely announced the future as determined by God, even if this raised questions as to the role of man's will, which allowed for actions that ran counter to the divine plan as signaled by the stars. ${ }^{161}$

In the sixteenth century, astrology also played an important role among laypeople. In the upper classes, including kings and princes, so-called nativities were very popular. Based on the precise time and place in which an individual was born, they predicted the course that person's life would take, including the dangers to his or her health. ${ }^{162}$ Wealthy contemporaries paid a fair penny when

158 Cod. 11206, fol. 15r.

159 See e.g. the extensive astromedical lecture by Georg Tannstetter in 1531 (Tannstetter, Artificium (2006)).

160 Wehrli, Clauser (1924), pp. $94 f$.

161 Kusukawa, Aspectio (1993); Brosseder, Bann (2004); Cooper, Approaches (2013); Hirai, New astral medicine (2014).

162 For an exemplary analysis of a nativity from the middle of the seventeenth century see Miller, Astrological diagnosis (1953). 
commissioning such personal nativities. ${ }^{163}$ Astrological calendars were among the most widespread kinds of printed matter, not only among the learned but among the population at large. By reading them, the reader could learn, depending on the constellations, which days were most favorable for certain activities such as sowing and harvesting, but also bloodletting, cupping, and other medical procedures. $^{164}$

It appears that some physicians earned considerable supplementary income by producing an astrological calendar for their native town or region each year, or by giving astrological prognoses to wealthy individuals. ${ }^{165}$ Both required extensive knowledge and considerable mathematical skill. General astronomical tables which displayed the course of the planets were available. Knowing how to read them required training, however. And calculations had to be adjusted to take the specific location into account - the location where the person in question was born or the area for which the calendar was to be valid. ${ }^{166}$

Some physicians became renowned for their astrological abilities. Girolamo Cardano is a well-known example. ${ }^{167}$ In the practice of most physicians, however, astrology played only a very modest role, at least as we can gather from the extant sources. In the numerous medical case histories, for example, which were being published at the time, planetary constellations are mentioned only rarely. The extensive astrological practice that John Napier and Simon Forman ran in the late sixteenth and early seventeenth century was very exceptional in this respect - they based their diagnoses on the constellation of the planets at the time of consultation. Both, Napier and Forman were learned laymen, however, not academically trained physicians. ${ }^{168}$ To date, no doctor medicinae with a halfway comparably substantial astrological practice has been identified for the time period in question, neither from England nor from German-speaking areas. ${ }^{169}$

\footnotetext{
163 Bauer, Rolle (1989).

164 Herbst, Arzt (2019).

165 In the 1490s, for example, Johann Roman Wonnecker sent an "almanac" to the Basel authorities, which he had prepared following the regulations (www.aerztebriefe.de/id/00038998, T. Walter).
}

166 E.g. Melhofer, Lasstafel (1543).

167 Grafton, Cardano's cosmos (1999); Siraisi, Clock (1997).

168 On Forman's and Napier's astrological practice, see MacDonald, Mystical Bedlam (1981); Sawyer, Patients (1986); Traister, Notorious astrological physician (2001); Kassell, Medicine (2005); see also https://casebooks.lib.cam.ac.uk/.

169 For the extensive astrological activities of Johannes Magirus, who practiced around 1650 in Berlin and Zerbst, see Schlegelmilch, Ärztliche Praxis (2018). 
The marginal significance of astrology in the physicians' everyday practice is also evidenced by Handsch's notebooks. The influence of the planetary constellations is explicitly discussed a handful of times only and some of these entries are mere excerpts from the works of others. ${ }^{170}$ Thus, without naming his source, he noted in a collection of poetic loci communes that people who had Venus and Mars in the sixth of the twelve houses of the classical nativity were exceptional in medicine. ${ }^{171}$ Elsewhere he remarked that three predictions of an astrologer had indeed come true for his mentor Gallo: that Gallo would embark on long, futile journeys (he had to accompany the Archduke on his travels), that he would need to be wary of a servant (one of them made off with fifteen talers), and that his wife would become pregnant and suffer a miscarriage. ${ }^{172}$ In other entries, he expressed skepticism. The more one became an astrologer, the more one turned away from Hippocrates; this Handsch gleaned from letters he read by Giovanni Manardi (1462-1536). ${ }^{173}$ He was moreover aware of the widely read and discussed attack on astrology that had been launched by Pico della Mirandola (1463-1494). ${ }^{174}$ Handsch also gave a thorough account of the answer to a question he had posed to the astrologer and physician Winkelmann as to whether astrology was useful in medical practice. Handsch wrote that Winkelmann had admitted to him privately that he, Winkelmann, had only wasted his time with it. If others were defending astrology, then it was only because they did not want to admit that all their efforts had been in vain. Handsch's sober conclusion was that astrology did not contribute anything to medicine. ${ }^{175}$

Handsch's extensive notes on the numerous patients treated by his medical colleagues and himself over the years allow for a more precise determination of the place of astrology in everyday medical practice. It becomes clear that the physicians Handsch knew and worked with paid consistent attention to only one "planet": the moon. It was much bigger in the sky compared to the other planets and, considering the tides, its influence on the sublunary world was indisputable. At most, physicians supplemented this by considering the additional influence of the signs of the zodiac or planets. Mattioli, for instance, declared bloodletting to be particularly effective when the moon was in a wet

170 Cod. 11240, foll. 83v-85r, excerpts on astrology from Gaudenzio Merula's Opus memorabilium; cf. Merula, Memorabilium (1556).

171 Cod. 9821 , fol. 259v.

172 Cod. 11205, fol. 191v.

173 Cod. 11200, fol. 126r, with a reference to Manardi, Epistolae (1557), p. 603 (book 15, letter 5); Cod. 11205, fol. 9r and fol. $564 \mathrm{v}$.

174 Cod. 9666, fol. 114r-115r.

175 Cod. 11205, fol. 253r-v; so far I have not been able to identfy this Winkelmann. 
zodiac sign. ${ }^{176}$ From experience, physicians believed they knew the influence of the moon on the body and on the course of a disease, and laypeople were also familiar with this. It was observed, for example, that the goiter from which the daughter of Heinrich Hirschperger had suffered for a number of years swelled when the moon was waxing and shrank when it was waning. ${ }^{177}$ One mother noticed that her son had his peculiar fits at new moon, full moon, and half-moon, when he would turn pale, scream, and move his right hand without saying a word. ${ }^{178}$ The daughter of Herr von Gendorf regularly took medications at the turn of the moon, when the moon was "im Bruch" ("breaking") as people said at the time, as a preventative measure against epileptic seizures. ${ }^{179}$ From experience, she knew that her condition would worsen then. ${ }^{180}$ It was apparently general knowledge that epilepsy was closely connected to the phases of the moon; Handsch in this regard wrote of a "symmetria". The seizures, he wrote, were most likely to happen at new moon, full moon, and half-moon, and for this reason, epilepsy was also referred to as moon sickness ("morbus lunaticus"). ${ }^{181}$

According to Handsch's notes, the court physicians Pietro Andrea Mattioli, Andrea Gallo, and Johannes Willenbroch considered the new moon to have particularly noticeable and generally unfavorable effects, and sometimes they even declared it to be a "contributing cause" ("concausa") of an illness. ${ }^{182}$ In some cases, this was backed up by empirical evidence, for example when a monk suffering from pleurisy or when a febrile gardener in Ambras died precisely on the day of the new moon. ${ }^{183}$ In the case of the severely ill wife of a chancery clerk, her convulsive fevers coincided with her monthly period at new moon. ${ }^{184}$ The heart tremble ("tremor cordis") of Maximilian II as well tended to occur at new moon and full moon. ${ }^{185}$ When the condition of his patients worsened, Mattioli consoled them by saying it was due to the new moon, thus characterizing it as temporary. ${ }^{186}$

176 Cod. 11207, fol. 93v; in another entry, on the administration of a purgative during an ultimately fatal course of disease, Handsch mentioned the conjunction of the moon with a planet (Cod. 11183, fol. 92r). Of course, the modern English word "lunatic" derives from the Latin word for "moon", "luna".

177 Cod. 11183 , fol. 140v.

178 Cod. 11205, fol. 241v.

179 Cod. 11206, fol. 178r.

180 Cod. 11205, fol. 293v.

181 Cod. 9650, fol. 36r-39r, copy of a letter from Handsch to Adam Lehner, 11 December 1559.

182 Cod. 11183, fol. 334r, fol. 339r and fol. 404r.

183 Ibid., fol. 339r and fol. 404r-v.

184 Ibid., fol. 484r.

185 Cod. 11158.

186 Cod. 11207, fol. 97r. 
When treating patients or prescribing bloodlettings or purging agents or other remedies, physicians likewise primarily took the new moon or the full moon into account, or, at most, considered whether the moon was waxing or waning. As a rule, Gallo prescribed his anti-epileptic powder the day before the new moon and in a serious case also before the full or half-moon. ${ }^{187}$ Mattioli declined to give the old Anna Welser a purgative because the moon was exactly at half, justifying this with the opinion of common people ("propter opinionem vulgi"). ${ }^{188}$

Insofar as the application of astrological ideas in the everyday medical practice of learned physicians was largely limited to the effects of the moon, the assumed influence of the stars had its place in the wider context of the impact of cyclical natural changes. Lunar phases essentially only differed from the seasons insofar as the latter were accompanied by perceptible changes in the air, temperature, and humidity.

Physicians considered the seasons to have great effects on internal physical processes. The winter produced bad humors and preserved them, Handsch noted. They also arose in the summer, but in the summer heat they could be more easily eliminated through dissolution ("per resolutionem"). ${ }^{189}$ With phrases such as, "The body closes itself off against the winter" and "nature and the blood close themselves off", a physician could explain to a patient seeking counsel why it was more difficult to rid him- or herself of morbid matter in the winter. ${ }^{190}$ One basic rule in therapeutic practice, which Handsch also saw his mentor Gallo apply, was that, in the case of chronic illnesses, one should wait until the weather was warmer before administering purging agents. When it got warmer, bad humors could more easily be mobilized and evacuated. ${ }^{191}$

The change of seasons in March was considered especially hazardous to health. ${ }^{192}$ This was because, as Handsch put it, just as the soil opens up in the springtime, a "mislaid bad humor" could break fresh ground within the body. ${ }^{193}$ The canicules, too, were associated with very unfavorable effects. ${ }^{194}$ As Handsch learned from a captain, wounds did not heal as well then and even mild injuries could have fatal consequences. ${ }^{195}$

187 Ibid., fol. 169r.

188 Cod. 11183, fol. 361v; Handsch wrote of quarter moons but what he meant by this was undoubtedly a quarter of a full moon cycle, i.e. half moon.

189 Ibid., fol. 457v.

190 Cod. 11206, fol. 176v and fol. 177r.

191 Cod. 11205, fol. 249r.

192 Cod. 11206, fol. 184r.

193 Ibid., fol. 185r, "verlegene böse Feuchtickeit".

194 Cod. 11205, fol. 249r.

195 Ibid., fol. 150r. 